\title{
СТАН ПРОТЕЇНАЗО-ІНГІБІТОРНОЇ СИСТЕМИ В ПЕЧІНЦ ЗА УМОВ ФОРМУВАННЯ ЕКСПЕРИМЕНТАЛЬНОГО АЛЕРГІЧНОГО АЛЬВЕОЛІТУ ТА КОРЕКЦІЯ ЙОГО ПОРУШЕНЬ ТІОТРИАЗОЛІНОМ
}

У роботі показано поступове зростання вмісту азоальбуміну, азоказеїну, азоколагену та зниження рівня в печінці альфа-2-макроглобуліну й альфа-1-інгібітора протеолізу, особливо на 24-ту, 34-ту і 44-ту доби розвитку експериментального алергічного альвеоліту. Встановлено позитивний коригувальний вплив тіотриазоліну на показники протеолізу й інгібіторів у печінці при даній моделі захворювання.

КЛЮЧОВІ СЛОВА: експериментальний алергічний альвеоліт, протеоліз, тіотриазолін.

ВСтуП. Проблема патогенезу, діагностики та лікування екзогенного алергічного альвеоліту (EAA) за останні десятиріччя набула особливої гостроти [3, 4]. Це захворювання важко піддається діагностиці через те, що перебігає під маскою різних недуг (грип, бронхіти, саркоїдоз тощо), і необхідне складне імунологічне дослідження. Разом із тим, дана патологія викликає розвиток різноманітних ускладнень, що зумовлює періоди непрацездатності та інвалідність [3, 4], тому це захворювання має соціально-економічне значення. На сьогодні до кінця не з'ясовано патогенез AA, зокрема не вивчено особливості змін стану протеїназоінгібіторної системи та вплив на нього тіотриазоліну.

У зв'язку з цим, метою даного дослідження було вивчити порушення протеїназо-інгібіторної системи та встановити можливість коригувальної дії тіотриазоліну.

МЕТОДИ ДОСЛІДЖЕННЯ. Дослідження було проведено на морських свинках (самцях) масою 180-220 г, яких поділили на шість груп: 1-ша - контроль (інтактні тварини); 2-га, 3-тя, 4-та і 5-та - морські свинки з експериментальним АА, відповідно, на 14-ту, 24-ту, 34-ту і 44-ту доби; 6-та - тварини з ЕАА після застосування препарату “Тіотриазолін” у дозі 100 мг/кг маси щоденно впродовж 10 днів (з 34-ї до 44-ї доби).

Експериментальний АА відтворювали за методом О. О. Орехова, Ю. А. Кириллова (1985) [2]. Декапітацію тварин здійснювали на 14-ту, (с) М. А. Пасічник, 2015. 24-ту, 34-ту і 44-ту доби ЕАА до та після лікування тіотриазоліном і забирали печінку для проведення біохімічних досліджень.

Визначення протеолітичної активності здійснювали за лізисом азоальбуміну, азоказеїну та азоколагену, альфа-1-інгібітора протеїназ ( $\alpha 1-І П)$, альфа-2-макроглобуліну ( $\alpha 2-\mathrm{M})$ - за методом К. Н. Веремеенко, О. П. Голобородько (1988) [1].

Статистичне опрацювання описаних цифрових даних проводили за методом Стьюдента.

РЕЗУЛЬТАТИ Й ОБГОВОРЕННЯ. СТаН ПрОтеолізу в тварин визначали за вмістом азоальбуміну, азоказеїну, азоколагену в печінці у динаміці розвитку експериментального алергічного альвеоліту.

Встановлено, що рівень азоальбуміну в печінці поступово зростав на 50,9 \% $(p<0,05)$, $81,1 \%(p<0,05), 97,2 \%(p<0,05)$ i $111,7 \%$ $(p<0,05)$ при ЕАА, відповідно, на 14-ту, 24-ту, 34-ту і 44-ту доби проти контролю (рис.), що свідчило про стимуляцію протеолітичної активності.

Результати біохімічних досліджень показали, що вміст азоказеїну поетапно підвищувався на 14-ту, 24-ту, 34-ту і 44-ту доби експерименту, відповідно, на 27,2 \% ( $p<0,05), 39,4 \%$ $(p<0,05), 52,3 \%(p<0,05)$ та 59,3\% $(p<0,05)$ відносно групи інтактних тварин (рис.), що свідчило про зростання активності протеолізу.

Вміст азоколагену в печінці збільшився на 14-ту, 24-ту, 34-ту і 44-ту доби експерименту, відповідно, на 30,8 \% (p<0,05), 37,1\% ( $<<0,05)$, $64,2 \%(p<0,05)$ та $77,7 \%(p<0,05)$ порівняно 3 


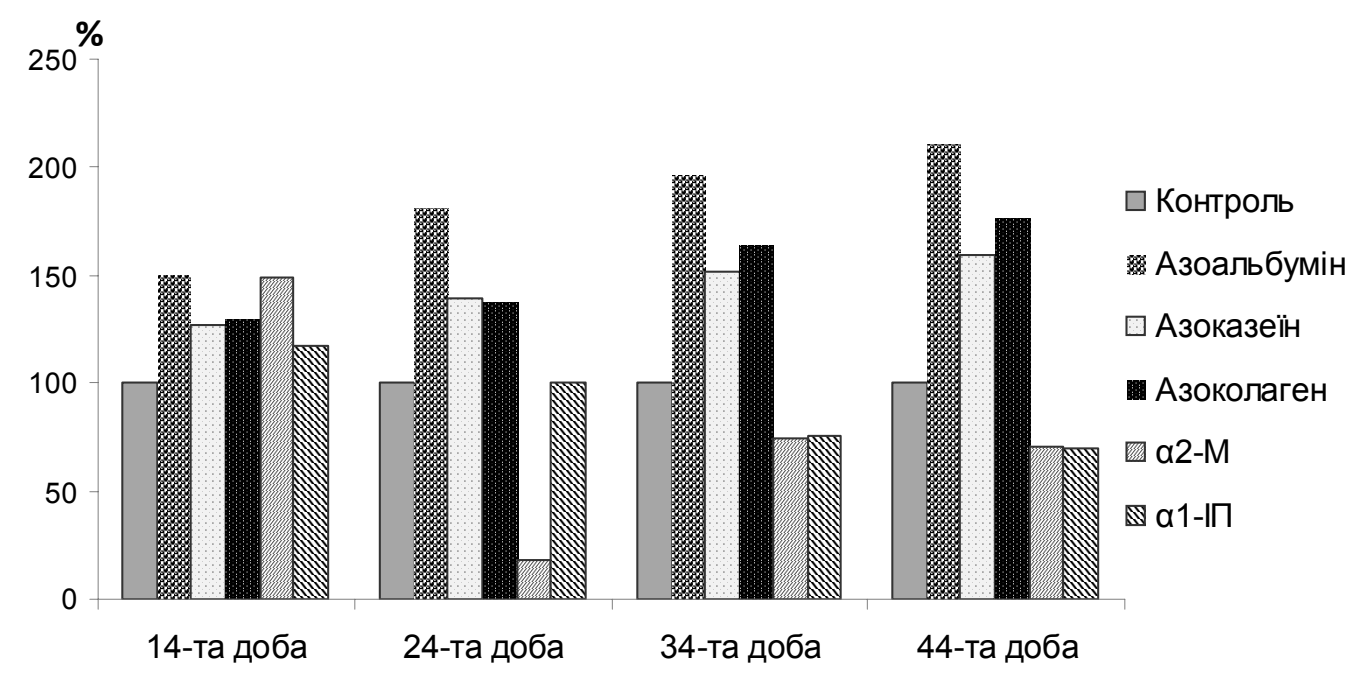

Рис. Стан протеїназо-інгібіторної системи в печінці при ЕАА (\% від контролю).

1-ю групою морських свинок, що вказувало на підвищення протеолітичної активності в печінці за умов розвитку АА (рис.). Отже, проведене дослідження азоальбуміну, азоказеїну, азоколагену в динаміці формування АA показало поступове зростання протеолітичної активності, яке досягнуло найвищих показників у найвіддаленіший термін спостереження (на 34-ту і 44-ту доби).

Стан інгібіторної системи в печінці оцінювали за рівнем $\alpha 2-\mathrm{M} \mathrm{i} \alpha 1-І$. Як свідчать результати досліджень, на 14-ту добу розвитку EAA відбувалося зростання вмісту $\alpha 2-\mathrm{M} \mathrm{на}$ 49,9 \% (р<0,05), а згодом, на 24-ту, 34-ту і 44-ту доби експерименту, спостерігали суттєве його зниження - на 82,6 \% (p<0,05), 26,7\% $(p<0,05)$ і 29,1\% (p<0,05) відповідно проти контролю (рис.). Визначення іншого інгібітора протеолізу

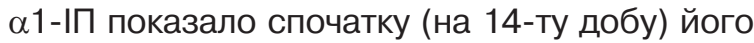
підвищення на 17,7 \% $(p<0,05)$ в печінці, на 24-ту добу цей показник перебував на рівні інтактної групи тварин і зазнав помітного зменшення на 25,3 \% $(p<0,05)$ і 30,4 \% $(p<0,05)$ відносно контролю (рис.).

Таким чином, вивчення показників протеолітичної активності та інгібіторної системи в печінці у динаміці формування EAA показало поступове зростання вмісту азоальбуміну, азоказеїну, азоколагену та зниження рівня

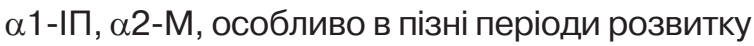
(34-та, 44-та доби) цієї експериментальної моделі хвороби, що вказувало на порушення рівноваги між протеолітичною та інгібіторною системами з перевагою у бік підвищення протеолізу.

Застосування тіотриазоліну зумовлювало зниження вмісту азоальбуміну на 27,8 \% $(p<0,05)$, азоказеїну - на 28,7\% $(p<0,05)$, азоколагену - на 21,3\% ( $<<0,05)$ та підвищення рівня $\alpha 2-\mathrm{M}$ на 18,2 \% (p<0,05) і $\alpha 1-І П-$ на 33,6 \% $(p<0,05)$ проти групи морських свинок з ЕАА, яким не вводили цього лікарського засобу, що свідчило про його коригувальний вплив на зазначені показники протеїназо-інгібіторної системи в печінці.

ВИСНОВОК. Експериментальний алергічний альвеоліт зумовлює зростання вмісту азоальбуміну, азоколагену, азоказеїну та зниження рівня інгібіторів протеаз у печінці, особливо на 34-ту і 44-ту доби експерименту. Встановлено коригувальну дію тіотриазоліну на зазначені показники при EAA.

\section{СПИСОК ЛІТЕРАТУРИ}

1. Веремеенко К. Н. Протеолиз в норме и при патологии / К. Н. Веремеенко, О. П. Голобородько, А. И. Кизим. - К. : Здоров'я, 1988. - 200 с.

2. Орехов О. О. Патоморфология легких и микроциркуляторного русла малого круга кровообращения при хроническом экспериментальном аллер- гическом альвеолите / О. О. Орехов, Ю. А. Кириллов // Арх. патол. - 1985. - № 10. - С. 54-61.

3. Регеда М. С. Алергічні захворювання легенів / М. С. Регеда. - Львів, 2009. - 342 с.

4. Регеда М. С. Екзогенний алергічний альвеоліт / М. С. Регеда, Р. Ю. Грицко, І. Г. Гайдучок. Львів, 2007. - 200 с. 


\section{СОСТОЯНИЕ ПРОТЕИНАЗО-ИНГИБИТОРНОЙ СИСТЕМЫ В ПЕЧЕНИ ПРИ ФОРМИРОВАНИИ ЭКСПЕРИМЕНТАЛЬНОГО АЛЛЕРГИЧЕСКОГО АЛЬВЕОЛИТА И КОРРЕКЦИЯ ЕГО НАРУШЕНИЙ ТИОТРИАЗОЛИНОМ}

\section{Резюме}

В работе показано постепенное возрастание содержания азоальбумина, азоказеина, азоколлагена и снижение уровня в печени альфа-2-макроглобулина и альфа-1-ингибитора протеолиза, особенно на 24-е, 34-е и 44-е сутки развития экспериментального аллергического альвеолита. Установлено положительное корригирующее влияние тиотриазолина на показатели протеолиза и ингибиторов в печени при этой модели заболевания.

КЛЮЧЕВЫЕ СЛОВА: экспериментальный аллергический альвеолит, протеолиз, тиотриазолин.

M. A. Pasichnyk DANYLO HALYTSKYI LVIV NATIONAL MEDICAL UNIVERSITY

\section{STATE OF PROTEINASE-INHIBITORY SYSTEM IN LIVER UNDER CONDITIONS OF FORMATION OF EXPERIMENTAL ALLERGIC ALVEOLITIS AND CORRECTION OF ITS DISTURBANCES WITH THIOTRIAZOLIN}

\section{Summary}

The papers shows a gradual increase of azoalbumin, azokasein, azokolagen and decrease of alpha 2-macroglobulin and alpha-1-inhibitor proteolysis in liver especially in the $24^{\text {th }}$, $34^{\text {th }}$ and $44^{\text {th }}$ days of experimental allergic alveolitis. It is shown a positive corrective action of thiotriazolin on indicators of proteolysis and inhibitors in liver during this model of disease.

KEY WORDS: experimental allergic alveolitis, proteolysis, thiotriazolin.

Отримано 17.12.14

Адреса для листування: М. А. Пасічник, Львівський національний медичний університет імені Данила Галицького, вул. Пекарська, 69, Львів, 79010, Україна. 